\title{
Soil macrofauna in wooded pasture with legume trees
}

\author{
Macrofauna do solo em pasto arborizado com leguminosas arbóreas
}

\author{
Lusimar Lamarte Gonzaga Galindo da Silva ${ }^{\mathrm{I}^{*}}$ Alexander Silva de Resende ${ }^{\mathrm{II}}$ \\ Paulo Francisco Dias ${ }^{\text {III }}$ Maria Elizabeth Fernandes CorreiaII Rafael Nogueira Scoriza ${ }^{\mathrm{IV}, \mathrm{I}}$
}

\section{ABSTRACT}

Grasslands afforestation aims at adding different soil uses in a way they become profitable for their owners. As such handling aims at minimizing impacts, the current study had as its goal the use of soil macrofauna in order to evaluate legume afforestation effects on the soil, regardless the depth. Thus, nitrogen fixing species were inserted onto grassland areas and the macrofauna collection was performed 6 years after their planting in the $0-10 \mathrm{~cm}, 10-20 \mathrm{~cm}$ and $20.30 \mathrm{~cm}$ layers, in winter and summer. Leguminous influence was different between depths and times of the year. It mostly favors communities under "Mimosa" Genus treetops. Besides, the effects from climatic seasonal variations on invertebrates were mitigated by the implementation of such legume trees.

Key words: soil invertebrates, silvopastoral, Brachiaria brizantha.

\section{RESUMO}

A arborização de pastagens visa a agregar diferentes usos do solo de um modo rentável a seu proprietário. Como este manejo visa a minimizar impactos, este trabalho objetivou utilizar a macrofauna do solo para avaliar os efeitos que a arborização por leguminosas causa sobre o solo, em suas diferentes profundidades. Para isso, foram inseridas espécies fixadoras de nitrogênio em uma pastagem, sendo a coleta da macrofauna realizada 6 anos após o plantio, nas camadas $0-10 \mathrm{~cm}, 10-20 \mathrm{~cm}$ e $20-30 \mathrm{~cm}$, no verão e inverno. A influência das leguminosas se deu de modo diferenciado entre as profundidades e estações do ano, com maior favorecimento da comunidade sob a copa das árvores do gênero Mimosa. Além disso, o efeito da variação sazonal climática sobre os invertebrados foi amenizada com a implantação das leguminosas arbóreas.

\author{
Palavras-chave: invertebrados do solo, silvipastoril, Brachiaria \\ brizantha.
}

\section{INTRODUCTION}

Grassland afforestation is an intentional combination of trees, pastures and cattle within the same area at the same time, incorporating wood production to livestock ventures (PORFÍRIO-DA-SILVA et al., 2010), thus diversify producer's incomes and help environmental and social sustainability in grasslands (NICODEMO et al., 2009; LIMA et al., 2013) Due to such practice, both shade and deposited biomass present the potential for enhancing soil fertility, increasing nitrogen availability for herbaceous forages, improving the quality of the forages and softening seasonal effects in grass production (LIMA et al., 2013).

The choice for using certain tree species must take into account aspects such as adaptation to the climate and soil conditions in the rural property, fast growth and environment supplies as shade for the cattle and nutrient recycling (PORFÍRIO-DA-SILVA et al., 2010). That is why MELOTTO et al. (2009) emphasize the use of woody species from succession initial ecological groups such as legume trees that, through nitrogen input, might significantly help the persistence and recovery of the pastures (NICODEMO et al., 2009).

Instituto de Pesquisas Jardim Botânico do Rio de Janeiro, Rua Jardim Botânico, 1008, Jardim Botânico, 22460-000, Rio de Janeiro, RJ, Brasil. E-mail: lusimar@jbrj.gov.br. "Corresponding author.

I'Embrapa Agrobiologia, Ecologia, Seropédica, RJ, Brasil.

IIIEmpresa de Pesquisa Agropecuária do Estado do Rio de Janeiro (Pesagro), Seropédica, RJ, Brasil. (in memorian).

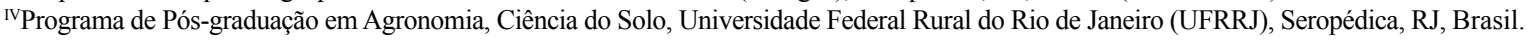
Received 11.27.13 Approved 11.18.14 Returned by the author 02.04.15 CR-2013-1569.R1 
As grassland afforestation with leguminous aims at minimizing livestock environmental impacts and increasing the quality of the soil (DIAS et al., 2006), thus it helps maintaining the different services provided by soil organic matter as well as promoting ecological interactions with the ecosystem (DUARTE et al., 2013). It is then worth interpreting the effects from anthropogenic interferences on the biological properties or processes that happen within the soil.

The soil macrofauna is represented by a diverse group in morphological and behavioral terms which includes worms, termites, ants, millipedes and others; all with body diameter larger than $2 \mathrm{~mm}$ (LAVELLE, 1997; VASCONCELLOS et al., 2013). They are key elements in soil food chain and perform support and regulation ecosystem services such as the creation of macropores that influence the ratio of water seepage and gas exchanges, participation in the formation of the soil as well as in the cycling of nutrients, increase in the resilience of the system and the fragmentation of vegetal tissues that will be humidified by microorganisms, thus increasing their decomposition rates (ROUSSEAU et al., 2012; BINKLEY \& FISHER, 2013; VASCONCELLOS et al., 2013).

Therefore, the current study aimed to assess the influence of grassland afforestation with leguminous species in the soil macrofauna and thus answer the following questions: (a) which is the depth in which the soil macrofauna under legume treetops is different from an area without afforestation? (b) Can the time of the year lead to changes in the soil macrofauna under treetops? (c) Are macrofauna groups associated with the use of a certain legume tree species?

\section{MATERIAL AND METHODS}

The current study is the follow up of a study by DIAS et al. (2007) which was performed in a pasture matrix with the species Brachiaria brizantha, cv 'Marandu', implemented in the year of 2000 on 1 hectare of a "Planossolo Haplico" which holds imperfect and bad drained soils responsible for the periodical formation of perched water tables (EMBRAPA, 2013). The area is located in Seropédica County, close to BR 465 road, within the geographic coordinate $22^{\circ} 48^{\prime} \mathrm{S}$ and $43^{\circ} 41^{\prime} \mathrm{W}$, with altitude of 33 meters. The climate in the region is categorized as Aw according to Köppen's system.

The area was wooded with four great potential leguminous species to be used in the recovering of degraded areas and in the fixation of nitrogen in mixed plantings (BALIEIRO et al., 2007; DIAS et al., 2007; AZEVÊDO et al., 2010; MELLO et al., 2012): Pseudosamanea guachapele (Kunth) Dugand, Acacia holosericea (Cunn, ex Don), Mimosa artemisiana (Heringer \& Paula) and Mimosa tenuiflora (Wild.) Poiret. Legume tree seedlings were produced from sowing them and transplanting them to the field in December 2001. They were inoculated with specific rhizobia strains, mycorrhizal fungy Gigaspora margarita and Glomus clarum.

Soil macrofauna samplings were performed in summer (December 2006) and in winter (July 2007) under half of the legume treetop shades, according to the method recommended by the Tropical Soil Biology Fertility program (ANDERSON \& INGRAM, 1993), thus holding a total of 8 repetitions to each studied woody species within a pasture and to the area without the influence of treetops (reference area). To do so, it was used a $25 \mathrm{~cm} \times 25 \mathrm{~cm}$ squared frame where the soil was collected from, within $0-10 \mathrm{~cm}, 10-20 \mathrm{~cm}$ and $20-30 \mathrm{~cm}$ depths. During extraction, the soil was placed on a tray and, with the help of a tweezers, all the visible invertebrates were taken out from it. They were placed in identified pots comprising $70 \%$ alcohol. Once in the lab, the invertebrates were identified according to big taxonomic groups as by DINDAL (1990). For evaluating the soil macrofauna community, densities from different groups and from the total of individuals by area and time were estimated, thus extrapolating the average for individuals $\mathrm{m}^{-2}$, also calculating the mean richness and the Pielou's equitability index by the formulation $-\sum$ pi. $\log 2 \mathrm{pi} / \log 2 \mathrm{R}$, in which "pi" is the relative frequency of individuals in each taxonomic group and " $R$ " is the richness defined as the number of different taxonomic units collected in each assessed area.

The collected data were tested for homogeneity (Cochran and Barttlet, 5\%) and normality (Lilliefors, 5\%). As data did not show normality and homogeneity, the Kruskal-Wallis (for more than two treatments) and the Wilcoxon (two treatments) non-parametric tests were used at $5 \%$. For comparing each one of the main groups, no cover pasture data were considered as reference, and pairwise comparisons were performed with each one of the leguminous species. The main components analysis was done in order to evaluate the relation among vegetation, depth and sampling time with soil macrofauna groups. 


\section{RESULTS AND DISCUSSION}

The number of individuals and the mean richness in macrofauna groups under both legume treetops and pasture presented differentiated patterns among depths and times of the year. In summer, there was a difference in the number of individuals in the $0-10 \mathrm{~cm}$ layer. The number of individuals found under the M. tenuiflora's treetop is bigger than that found under the B. brizantha. Yet, in winter, there was no difference among the macrofauna within each depth (Table 1).

In overall terms, the number of individuals and the mean richness were higher on the soil surface. However, for the macrofauna under the M. artemisiana's treetop there were no differences among the first layers as well as the number of individuals and mean richness in summer. As for the P. guachapele, there was no difference among the same ranges for the number of individuals in winter. Even though being punctual, these outcomes might indicate the influence of such leguminous species on the vertical distribution of macrofauna in the soil and the absence of differences shows the conditions found by the invertebrates for exploring the soil surface environment, thus enabling their existence and/or moves in it. SILVA et al. (2011) got to similar conclusions when evaluated soil macrofauna within agricultural cultivation systems where, in the pasture cultivated area, there was no difference in the number of individuals between the $0-10 \mathrm{~cm}$ and $10-20 \mathrm{~cm}$ layers and their number was bigger than that in the 20-30cm layer.

The Pielou's equitability index showed a lower prevalence of groups in the B. brizantha in the $0-10 \mathrm{~cm}$ layer and the most outlier values were found in winter. Within the $10-20 \mathrm{~cm}$ layer it was not possible to observe a clear pattern, mainly when the two seasons were taken under consideration. However, it was observed the stronger prevalence of groups in the last sampled soil layer, fact that is related to lower mean richness. The layer just showed the oligochaeta, coleopteran (adult and maggot) and formicidae groups (Table 2). In a comparative way, DIAS et al. (2006), by evaluating the influence of afforestation on leguminous pastures, verified a favoring of the fauna diversity and lower prevalence of groups when compared to pastures under full sunlight, the same as seen in the current study about $\boldsymbol{A}$. holocericea during winter. According to DIAS et al. (2006), the microclimatic conditions and the food resources generated by afforestation were able to attract more individuals from different groups.

Table 1 - Soil macrofauna under legume treetops and pasture in different depths in the soil. ${ }^{\text {a } V a l u e s ~ w i t h ~ l o w e r c a s e ~ s u b t i t l e s ~(c o m p a r i s o n ~}$ among vegetation types) and Acapital letters (comparison among depths) in an equal column are not different according to the Kruscal-Wallis test at 5\%.

\begin{tabular}{|c|c|c|c|c|c|c|}
\hline & Individuals $\mathrm{m}^{-2}$ & $\begin{array}{l}\text { Richnes } \\
\text { Average }\end{array}$ & Pielou & Individuals $\mathrm{m}^{-2}$ & $\begin{array}{l}\text { Richness } \\
\text { Average }\end{array}$ & Pielou \\
\hline A. holosericea & $1912^{\mathrm{aA}}$ & $8.5^{\mathrm{aA}}$ & 0.30 & $564^{\mathrm{abA}}$ & $6.5^{\mathrm{aA}}$ & 0.69 \\
\hline M. artemisiana & $1482^{\mathrm{aA}}$ & $7.6^{\mathrm{aA}}$ & 0.49 & $1230^{\mathrm{abA}}$ & $6.75^{\mathrm{aA}}$ & 0.65 \\
\hline M. tenuiflora & $826^{\mathrm{aA}}$ & $7.5^{\mathrm{aA}}$ & 0.75 & $932^{\mathrm{aA}}$ & $6.0^{\mathrm{aA}}$ & 0.55 \\
\hline P. guachapele & $738^{\mathrm{aA}}$ & $7.0^{\mathrm{aA}}$ & 0.66 & $412^{\mathrm{abA}}$ & $5.8^{\mathrm{aA}}$ & 0.63 \\
\hline B. brizantha & $1334^{\mathrm{aA}}$ & $6.3^{\mathrm{aA}}$ & 0.48 & $312^{\mathrm{bA}}$ & $4.0^{\mathrm{aA}}$ & 0.53 \\
\hline A. holosericea & $58^{\mathrm{aB}}$ & $1.3^{\mathrm{aB}}$ & 0.36 & $176^{\mathrm{aB}}$ & $2.6^{\mathrm{aB}}$ & 0.73 \\
\hline M. artemisiana & $274^{\mathrm{aAB}}$ & $2.0^{\mathrm{aB}}$ & 0.64 & $104^{\mathrm{aAB}}$ & $2.0^{\mathrm{aAB}}$ & 0.61 \\
\hline M. tenuiflora & $144^{\mathrm{aB}}$ & $2.1^{\mathrm{aB}}$ & 0.49 & $118^{\mathrm{aB}}$ & $2.0^{\mathrm{aB}}$ & 0.55 \\
\hline P. guachapele & $128^{\mathrm{aAB}}$ & $2.1^{\mathrm{aB}}$ & 0.53 & $56^{\mathrm{aB}}$ & $1.3^{\mathrm{aB}}$ & 0.51 \\
\hline B. brizantha & $226^{\mathrm{aB}}$ & $2.3^{\mathrm{AB}}$ & 0.52 & $30^{\mathrm{aB}}$ & $1.4^{\mathrm{aB}}$ & 0.83 \\
\hline A. holosericea & $14 \mathrm{aB}$ & $0.4^{\mathrm{aB}}$ & $\begin{array}{c}0 \mathrm{~cm}-- \\
0.86\end{array}$ & $26^{\mathrm{aB}}$ & $0.6^{\mathrm{aB}}$ & 0.90 \\
\hline M. artemisiana & $20 \mathrm{aB}$ & $0.6^{\mathrm{aB}}$ & 0.72 & $48^{\mathrm{aB}}$ & $1.3^{\mathrm{aB}}$ & 0.80 \\
\hline M. tenuiflora & $18 \mathrm{aB}$ & $0.5^{\mathrm{aB}}$ & 0.76 & $12^{\mathrm{aB}}$ & $0.6^{\mathrm{aB}}$ & 0.90 \\
\hline P. guachapele & $20^{\mathrm{aB}}$ & $0.6^{\mathrm{aB}}$ & 0.72 & $10^{\mathrm{aB}}$ & $0.6^{\mathrm{aB}}$ & 0.86 \\
\hline B. brizantha & $38^{\mathrm{aB}}$ & $0.4^{\mathrm{aB}}$ & 0.63 & $2^{\mathrm{aB}}$ & $0.1^{\mathrm{aB}}$ & 0.00 \\
\hline
\end{tabular}


Table 2 - Main soil macrofauna groups under legume treetops and pasture in different depths in the soil in summer and winter. The letter "a" does not present and "b" presents difference in regards to B. brizantha according to the Wilcoxon test at $5 \%$.

\begin{tabular}{|c|c|c|c|c|c|c|c|c|c|c|}
\hline & 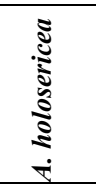 & 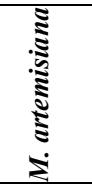 & 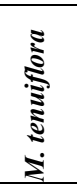 & 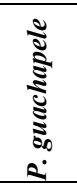 & 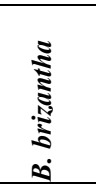 & 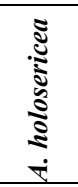 & 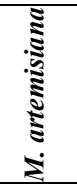 & 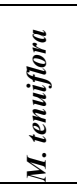 & 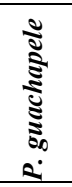 & 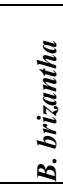 \\
\hline \multicolumn{11}{|c|}{ - } \\
\hline Araneae & $36 a$ & $22 \mathrm{a}$ & $74 a$ & $46 a$ & $58^{*}$ & $2 \mathrm{a}$ & $8 \mathrm{a}$ & $10 \mathrm{a}$ & $2 \mathrm{a}$ & $2 *$ \\
\hline Coleoptera & $40 \mathrm{a}$ & $24 a$ & $40 \mathrm{a}$ & $20 a$ & $34 *$ & $60 \mathrm{~b}$ & $36 \mathrm{~b}$ & $32 b$ & $16 \mathrm{~b}$ & 2 \\
\hline Formicidae & $1558 \mathrm{a}$ & $1004 \mathrm{a}$ & $272 a$ & $362 \mathrm{a}$ & $1026^{*}$ & $70 \mathrm{a}$ & $216 \mathrm{~b}$ & $358 \mathrm{~b}$ & $40 \mathrm{a}$ & $82 *$ \\
\hline Isopoda & 36 & 60 & 188 & 116 & 0 & $6 a$ & $40 \mathrm{a}$ & $10 \mathrm{a}$ & $16 a$ & $2 *$ \\
\hline L. Coleoptera & $38 \mathrm{a}$ & $46 \mathrm{a}$ & $38 \mathrm{a}$ & $26 \mathrm{a}$ & $60 *$ & $40 \mathrm{a}$ & $194 b$ & $118 \mathrm{~b}$ & $54 a$ & $26^{*}$ \\
\hline Oligochaeta & $116 \mathrm{a}$ & $62 \mathrm{a}$ & $144 b$ & $94 \mathrm{a}$ & $116^{*}$ & $198 \mathrm{a}$ & $290 \mathrm{a}$ & $368 b$ & $220 \mathrm{a}$ & $166^{*}$ \\
\hline Araneae & 0 & $2 a$ & 0 & $6 a$ & $4 *$ & $14 \mathrm{a}$ & 0 & 0 & 0 & $2 *$ \\
\hline Coleoptera & 0 & 0 & 0 & 4 & 0 & $4 a$ & 0 & $4 a$ & 0 & $4 *$ \\
\hline Formicidae & 0 & $14 \mathrm{a}$ & $2 b$ & 0 & $152 *$ & $72 \mathrm{a}$ & 0 & $4 a$ & 0 & $2 *$ \\
\hline L. Coleoptera & $4 \mathrm{~b}$ & $14 \mathrm{a}$ & $30 \mathrm{a}$ & $20 \mathrm{a}$ & $14^{*}$ & $22 b$ & $44 b$ & $26 \mathrm{~b}$ & $8 \mathrm{a}$ & $2 *$ \\
\hline Oligochaeta & $52 \mathrm{a}$ & $90 \mathrm{a}$ & $102 b$ & $90 \mathrm{~b}$ & $52 *$ & $44 b$ & $56 b$ & $82 b$ & $46 b$ & $14 *$ \\
\hline Formicidae & 0 & 0 & 0 & $4 a$ & $32 *$ & 8 & 24 & 6 & 6 & 0 \\
\hline L. Coleoptera & $4 a$ & $4 a$ & $4 a$ & 0 & $6^{*}$ & 14 & 6 & 2 & 0 & 0 \\
\hline Oligochaeta & 10 & 16 & 14 & 16 & 0 & $4 a$ & $12 \mathrm{a}$ & $2 a$ & $2 \mathrm{a}$ & $2 *$ \\
\hline
\end{tabular}

In regards to it, the few and punctual differences observed in the macrofauna among vegetation types, as verified in table 1 , might be an indication that within the pasture environment the main influences over invertebrates are humidity and the shade provided by legume treetops, regardless the species. Then, the need for a pairwise comparison between pasture and leguminous species becomes more evident. Such comparison assesses the change brought to macrofauna groups by this particular leguminous species in the environment, in each one of the seasons, as shown in table 2.

In winter, on the surficial layer, there was a large presence of formicidae, a big number of individuals from the heteroptera group under the $\boldsymbol{A}$. holosericea treetop and a big number of oligochaeta under the $\boldsymbol{M}$. tenuiflora treetop when compared to the woody free pasture area. It is also worth highlighting the absence of isopoda in the pasture. Within the $10-20 \mathrm{~cm}$ layer there was a bigger number of formicidae and coleoptera larva and a smaller number of oligochaeta in the pasture when compared with the woody species. Yet, in the last layer, it was pinpointing the absence of oligochaeta in the pasture, only. In studies by DIAS et al. (2006) and PORTILHO et al. (2011), the formicidae group stood out in consortia formed by legume trees in pastures. The formicidae group was followed by the oligochaeta one, which practically doubled in the woody pasture when compared to those from in full sunlight pastures. VASCONCELLOS et al. (2013) associated the high abundance of ants during the dry period to greater availability and lower competition for food.

In summer, the coleopteran (adult and larva), formicidae and oligochaeta groups under "mimosa" species treetops were larger than in the pasture, in the $0-10 \mathrm{~cm}$ layer. Besides, coleoptera were in bigger number on all legume trees. Practically the same happened for coleoptera and oligochaeta larva in the following $(10-20 \mathrm{~cm})$ soil layer. As for the last layer $(20-30 \mathrm{~cm})$, the absence of groups in the pasture did not allow the comparison, except for the oligochaeta, which did not present differences. According to DIAS et al. (2006) the presence of legume trees helps understanding increases on fauna density, richness and diversity in the soil, mainly in the coleopteran, araneae and formicidae groups.

Besides microclimatic changes, afforestation in pastures may also create greater balance within the ecosystem (PORTILHO et al., 2011), fact that would reduce the effects of seasonal changes on macrofauna communities in the soil. 
However, by performing a direct comparison on the number of individuals among seasons, it was observed the stronger effect of such changes over the two first soil layers that always present bigger numbers in winter. Among leguminous, only the $\boldsymbol{P}$. guachapele presented differences in the two first layers since $\boldsymbol{A}$. holosericea just showed differences in the first layer, in the pasture. There was a difference in the $10-20 \mathrm{~cm}$ layer, only. Usually, P. guachapele presents $70 \%$ of its roots in the $0-20 \mathrm{~cm}$ depth for this soil type, besides its capability of forming symbiotic associations and of inputting big amounts of nitrogen into the soil (BALIEIRO et al., 2005). It may seasonally and strongly influence the organisms found in there. In turn, B. Brizantha presented low seasonal influence and most of its roots were in the superficial soil layers (REZENDE et al., 2011), thus exerting little influence on the deep soil layers.

The aforementioned results its in opposition to what is usually found in the literature, in other words, they favor the fauna in the soil with better rainfall and temperature conditions, just as in summer. However, within the area where the current study was performed, the soil type (Planossolo halico) may have caused a negative effect on the community of invertebrates in the soil during summer, once it was a soil up to floods. Amid the groups, just the oligochaeta presented a more expressive number at this time of the year, mainly within the superficial soil layers associated to organic residues. According to JARDEVESKI \& PORFÍRIO-DA-SILVA, (2005) in summer worms are more active, even reproductively.

Thus, it is seen that the season and soil depth are determining factors for the number of individuals of the soil macrofauna and the vegetation type is a secondary aspect. Thus, by relating these two factors in an analysis on main components (Figure 1), it was verified that the $0-10 \mathrm{~cm}$ layer is the one that mostly represents the invertebrate communities, both due to the size of its vector and direction, similar to the groups. Besides, the influence of $\boldsymbol{P}$. guachapele on the community was similar to that in the pasture, going in opposition to

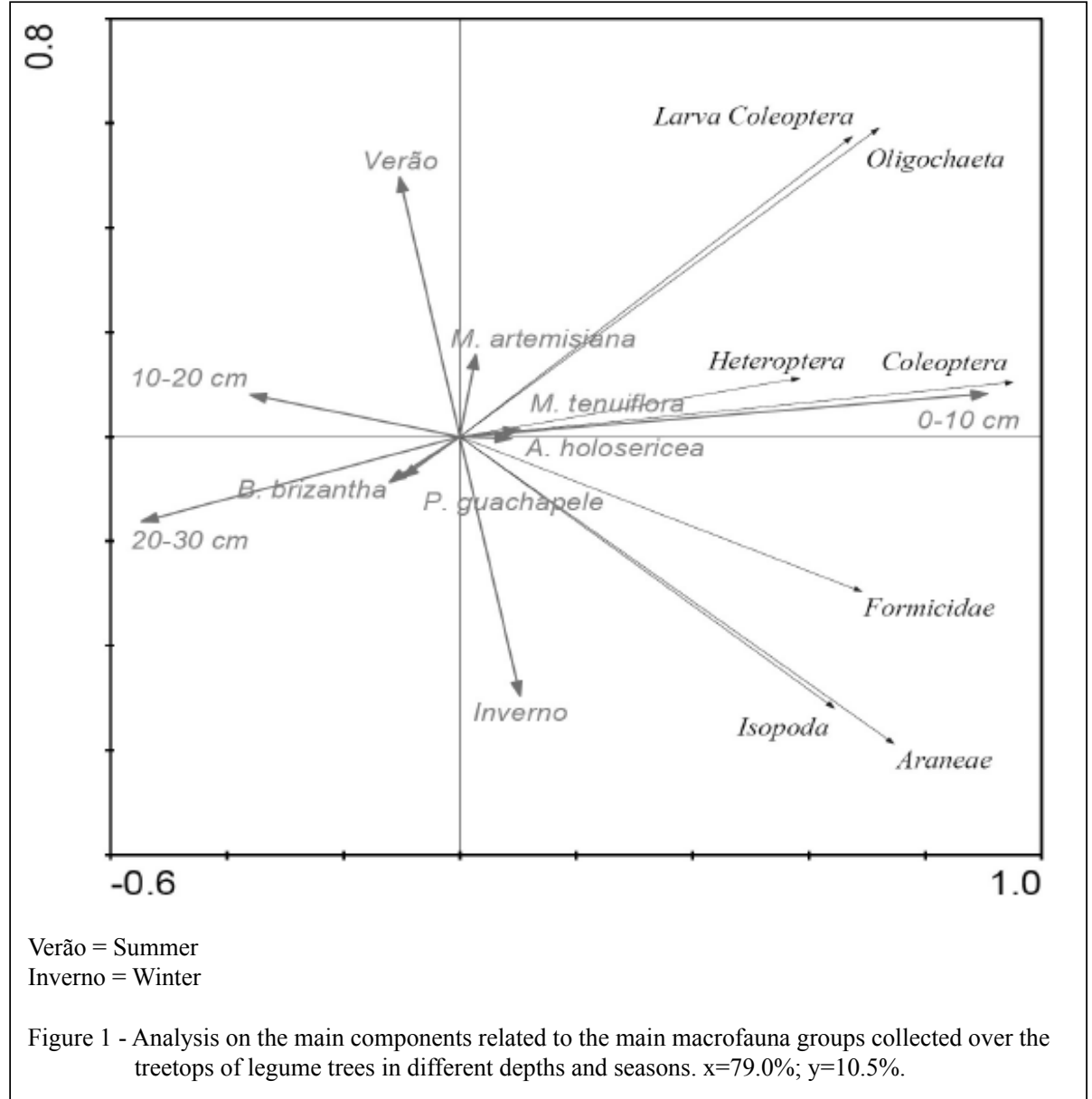


the other leguminous that presented stronger relation with the main group of invertebrates in the soil.

\section{CONCLUSION}

Pasture afforestation caused vertical changes in the soil macrofauna, better favoring communities under the treetop of plants from "Mimosa" genus. Besides, seasonal climatic variation effects over invertebrates were minimized by the implementation of these leguminous.

\section{ACKNOWLEDGEMENTS}

Instituto de Pesquisas Jardim Botânico do Rio de Janeiro, Universidade Federal Rural do Rio de Janeiro (UFRRJ) and Embrapa-Agrobiologia.

\section{REFERENCES}

ANDERSON, J.M.; INGRAM, J.S.I. Tropical soil biological and fertility: a handbook of methods. 2.ed. Wallingford: CAB International, 1993.

AZEVÊDO, S.M.A. et al. Crescimento de plântulas de Jurema Preta (Mimosa tenuiflora (Wild) Poiret) em solos de áreas degradadas da Caatinga. Environmental Engineering, v.9, n.3, p.150-160, 2012. Available from: <http://ferramentas.unipinhal. edu.br/ojs/engenhariaambiental/viewarticle.php?id=745>. Accessed: Nov. 12, 2013.

BALIEIRO, F.C. et al. Biomassa de raízes e regime hídrico do solo em plantio de Pseudosamenea guachapele (Kunth) Harms em um Planossolo Háplico. Floresta, v.35, n.2, p.221-230, 2005. Available from: <http://ojs.c3sl.ufpr.br/ojs2/index.php/floresta/ article/view/5217/3911>. Accessed: Nov. 12, 2013.

BALIEIRO, F.C. et al. Evaluation of the throughfall and stewflow nutriente contentes in mixed and pure plantations of Acacia mangium, Pseudosamenea guachapele and Eucalyptus grandis. Revista Árvore, v.31, n.2, p.339-346, 2007. Avaivale from: $<$ http://www.scielo.br/pdf/rarv/v31n2/a17v31n2.pdf $>$. Accessed: Nov. 12, 2013. doi: 10.1590/S0100-67622007000200017.

BINKLEY, D.; FISHER, R.F. Ecology and management of forest soils. 4.ed. Oxford: Wiley-Blackwell, 2013. Total de 401 p.

DIAS, P.F. et al. Efeito de leguminosas arbóreas sobre a macrofauna do solo em pastagem de Brachiaria brizantha cv. 'Marandu'. Pesquisa Agropecuária Tropical, v.37, n.1, p.38-44, 2007. Available from: <http://www.revistas.ufg.br/index.php/pat/ article/view/1863>. Accessed: Nov. 12, 2013.

DIAS, P.F. et al. Árvores fixadoras de nitrogênio e macrofauna do solo em pastagem de híbrido de Digitaria. Pesquisa Agropecuária Brasileira, v.41, n.6, p.1015-1021, 2006. Available from: <http://www.scielo.br/ scielo.php?script $=$ sci_arttext\&pid $=S 0100-204 X 2006000600018>$. Accessed: Sept. 16, 2013. doi: 10.1590/s0100-204x2006000600018.

DINDAL, D. Soil biology guide. New York: John Wiley and Sons, 1990. 1349 p.
DUARTE, E.M.G. et al. Decomposition and nutrient release in leaves of Atlantic Rainforest tree species used in agroforestry systems. Agroforest Systems, v.87, n.4, p.835-847, 2013. Available from: <http://link.springer.com/article/10.1007/ s10457-013-9600-6>. Accessed: Nov. 12, 2013. doi: http:// dx.doi.org/10.1007/s10457-013-9600-6.

EMBRAPA (EMPRESA BRASILEIRA DE PESQUISA AGROPECUÁRIA). Sistema brasileiro de classificação de solos. 3.ed. Brasília: Embrapa, 2013. 306 p.

JARDEVESKI, R.; PORFÍRIO-DA-SILVA, V. Minhocas em uma pastagem arborizada na região nordeste do estado do Paraná, Brasil. Boletim de Pesquisa Florestal, n.51, p.17-31, 2005. Available from: <http://www.cnpf.embrapa.br/publica/boletim/ boletarqv/boletim51/boletim51_pag17-31.pdf >. Accessed: Nov. $12,2013$.

LAVELLE, P. Faunal activities and soil processes: adaptative strategies that determine ecosystem function. Advances in Ecological Research, v.27, p.93-132, 1997. Available from: $<$ http://horizon.documentation.ird.fr/exl-doc/pleins_textes/pleins textes_6/b_fdi_45-46/010008338.pdf>. Accessed: Sept. 16, 2013.

LIMA, P.R. et al. Espécies lenhosas nativas com potencial de uso em sistema silvipastoril em Mato Grosso do Sul. Revista Agrogeoambiental, v.5, n.2, p.67-78, 2013. Available from: $<$ http:// joomla3.ifsuldeminas.edu.br/ ojs/index.php/Agrogeoambiental/ article/view/504/493>. Accessed: Nov. 12, 2013.

MELLO, A.H. et al. Estabelecimento de fungos micorrízicos arbusculares em mudas de Mimosa artemisiana em diferentes substratos. Revista Agroecossistemas, v.4, n.2, p.52-66, 2012. Available from: <http://www.periodicos.ufpa.br/index.php/ agroecossistemas/article/viewFile/1213/1643>. Accessed: Nov. $12,2013$.

MELOTTO, A. et al. Sobrevivência e crescimento inicial em campo de espécies florestais nativas do Brasil Central indicadas para sistemas silvipastoris. Revista Árvore, v.33, n.3, p.425432, 2009. Available from: <http://www.scielo.br/pdf/rarv/ v33n3/04.pdf $>$. Accessed in: Nov. 12, 2013. doi: 10.1590/S010067622009000300004 .

NICODEMO, M.L.F. et al. Desenvolvimento inicial de espécies florestais em sistema silvipastoril na região sudeste. Pesquisa Florestal Brasileira, n.60, p.89-92, 2009. Available from: $<$ http:// www.cnpf.embrapa.br/pfb/index.php/pfb/article/view/49/53>. Accessed Nov. 12, 2013. doi: 10.4336/2009.pfb.60.89.

PORFÍRIO-DA-SILVA, V. et al. Arborização de pastagens com espécies florestais madeireiras. Colombo: Embrapa Florestas, 2010. 48 p.

PORTILHO, I.I.R. et al. Fauna invertebrada e atributos físicos e químicos do solo em sistemas de integração lavourapecuária. Pesquisa Agropecuária Brasileira, v.46, n.10, p.1310-1320, 2011. Available : <http://www.scielo.br/pdf/pab/ v46n10/46v10a26.pdf $>$. Accessed: Nov. 12, 2013. doi: 10.1590/ S0100-204X2011001000027.

REZENDE, A.V. et al. Características morfofisiológicas da Brachiaria brizantha cv. 'Marandu' em resposta à adubação fosfatada. Revista Agrarian, v.4, n.14, p.335-343, 2011. Available from: <http://www.periodicos.ufgd.edu.br/index.php/ agrarian/article/view/1145/926>. Accessed: Nov. 12, 2013. 
ROUSSEAU, G.X. et al. Indication soil quality in cacao-based agroforestry systems and old-growth forest: the potential of soil macrofauna assemblage. Ecological Indicators, v.23, p.535-543, 2012. Available from: <http://www.sciencedirect.com/science/ article/pii/S1470160X12002075>. Accessed: Sept. 16, 2013. doi: 10.1016/j.ecolind.2012.05.008.

SILVA, R.F. et al. Análise conjunta de atributos físicos e biológicos do solo sob sistema de integração lavoura-pecuária. Pesquisa Agropecuária Brasileira, v.46, n.10, p.1277-
1283, 2011. Available from: <http://www.scielo.br/pdf/pab/ v46n10/46v10a22.pdf> . Accessed: Nov. 12, 2013. doi: 10.1590/ S0100-204X2011001000023.

VASCONCELLOS, R.L.F. et al. Soil macrofauna as an indicator of soil quality in a undisturbed ripariam forest and recovering sites of different ages. European Journal of Soil Biology, v.58, p.105-112, 2013. Available from: <http://www.sciencedirect.com/ science/article/pii/S1164556313000642>. Accessed: Sept. 16, 2013. doi: 10.1016/j.ejsobi.2013.07.001. 